\title{
Memahami Perilaku Kekerasan Penyidik Polri terhadap Tersangka pada Tahapan Pra-Adjudikasi (Studi Kajian Ilmu Hukum Normatif Dengan Pendekatan Psikologi Hukum Dalam Sistem Peradilan Pidana)
}

\author{
Ramlani Lina Sinaulan \\ Universitas Jayabaya, Jakarta \\ e-mail: linasinaulan@gmail.com
}

\begin{abstract}
On the development of law (rechtsbeoefening) both practical and theoretical, a scientist Law (academics and legal practitioners) often ignore the studies of the social aspects. In this case, a scientist Law (academics and legal practitioners) are trapped and confined on the nature of Legal Studies as a normative science. Thus, the development often collide in the level of practice of law in relation to the fulfillment of public sense of justice. In fact, the law enforcement authorities, especially police investigators, based on the pattern of education, obviously prefers cultural improvement of law and override the Legal Psychology. So, almost certainly, a police investigator in carrying out its duties and functions will never escape, in fact, are still stuck with the principle inquisatoir in examinations investigation.
\end{abstract}

Keywords: law psychology, law science, culture of organization, police, inspector

\begin{abstract}
Abstrak
Pada pengembanan hukum (rechtsbeoefening) baik yang bersifat praktis maupun teoretis, seorang Ilmuwan Hukum (akademisi dan praktisi hukum) seringkali mengabaikan kajiankajian dari aspek sosial. Dalam hal ini, seorang Ilmuwan Hukum (akademisi dan praktisi hukum) terjebak dan terkungkung pada sifat Ilmu Hukum sebagai ilmu normatif. Sehingga, pengembanannya seringkali berbenturan dalam tataran praktik hukum dalam kaitannya pemenuhan rasa keadilan masyarakat. bahkan, terhadap Aparat Penegak Hukum khususnya Penyidik Polri, berdasarkan pola pendidikannya, jelas sekali lebih mengutamakan perbaikan budaya hukum dan mengesampingkan Psikologi Hukum. Sehingga, hampir bisa dipastikan, seorang Penyidik Polri dalam melaksanakan tugas dan fungsinya tidak akan pernah lepas, bahkan, masih terjebak dengan asas inquisatoir dalam melakukan pemeriksaan penyidikan.
\end{abstract}

Kata Kunci: psikologi hukum, ilmu hukum, budaya organisasi, penyidik, Polri

\section{Pendahuluan}

Konsekuensi dianutnya negara hukum dalam Pasal 1 ayat (3) Undang-Undang Dasar Negara Republik Indonesia Tahun 1945 (UUD RI 1945), dengan konsep Negara Hukum Kesejahteraan, adalah menjadikan setiap Pejabat Publik memiliki keluasan bertindak dalam kerangka mewujudkan kesejahteraan umum berdasarkan cita hukum (keadilankepastian-kemanfaatan). Keluasan bertindak dari Pejabat Publik dalam konteks welfare state tersebut, dilengkapi dengan asas diskresi sehingga terlepas dari kungkungan kekakuan pasal-pasal yang seringkali tidak mengakomodir dinamika perkembangan hidup kemasyarakatan,

Pada ranah proses penegakan hukum pidana, Kepolisian Republik Indonesia (Polri), berdasarkan Pasal 2 UndangUndang Nomor 2 Tahun 2002 tentang Kepolisian Republik Indonesia (UU No. 2/2002) merupakan pelaksana dari fungsi pemerintahan pada bidang pe-meliharaan keamanan dan ketertiban masyarakat, penegakan hukum, perlin-dungan, pengayoman, dan pelayanan kepada masyarakat.

Keluasan bidang yang merupakan tugas dan fungsi Polri tersebut, pada 
hakikatnya tidak terlepas dari perwujudan tujuan bernegara, yaitu kesejahteraan umum sebagaimana termuat dalam Alinea IV Pembukaan UUD RI 1945. Hal tersebut merupakan konsekuensi dari diletakkannya Polri sebagai institusi penegak hukum yang berada di bawah kekuasaan eksekutif yang memiliki beban kerja dalam menjalankan pemerintahan.

Pergeseran paradigma, tugas dan fungsi Polri dalam hal penegakan hukum pidana, memunculkan permasalahan tersendiri dalam tataran Praktik Hukum dalam mengimplementasikan Ilmu Hukum-nya. Sebagaimana diketahui bersama, bahwa dalam konteks pengaturan HIR, Polri bergerak berdasarkan asas inquisatoir sampai pada tahun 1981. Baru setelah tahun 1981, dengan diundangkan dan disahkannya Undang-Undang Nomor 8 Tahun 1981 tentang Hukum Acara Pidana atau dikenal dengan nama Kitab UndangUndang Hukum Acara Pidana (KUHAP), pergeseran paradigma tersebut memunculkan asas accusatoir yang menggeser asas inquisatoir dalam proses pemeriksaan baik pada tingkat penyidikan, penuntutan maupun pemeriksaan di depan persidangan.

Perbedaan asas inquisatoir dan asas accusatoir terletak pada cara pandang Penyidik terhadap norm addressat (pihak yang tertuju berdasarkan norma dalam pasal-pasal pidana). Dalam konteks asas inquisatoir, titik tolak Penyidik Polri adalah si pembuat dari perbuatan pidana. Artinya, si terlapor/terduga/tersangka, secara pribadi merupakan objek dari pemeriksaan itu sendiri. Sehingga, si pembuat perbuatan pidana tersebut merupakan objek pemeriksaan dan bukan perbuatannya. Sedangkan pada asas accusatoir, titik pandang pemeriksaan bukan kepada si pembuat perbuatan pidana, namun terfokus pada perbuatannya itu sendiri (vide Pasal 117 ayat (2) KUHAP). Sehingga, Penyidik Polri wajib mencatat secara teliti dan detail setiap keterangan yang diberikan oleh si terlapor/terduga/tersangka.
Pada realitasnya, pergeseran paradigma tersebut tidak terealisasi sebagaimana diinginkan oleh KUHAP. Melalui beberapa penelitian empiris yang dilakukan oleh beberapa Lembaga Swadaya Masyarakat (LSM) yang independen menunjukan angka statistik yang jauh dari harapan pembentuk undang-undang.

Pada buku berjudul "Mengungkap Kejahatan dengan Kejahatan" yang diterbitkan Lembaga Bantuan Hukum (LBH) Jakarta (2008) diuraikan bahwa aparat kepolisian masih dominan melakukan kekerasan. Pada survei LBH Jakarta tahun 2005 dan 2008, dalam buku itu, disebutkan, responden yang menyatakan telah mendapat kekerasan dari aparat kepolisian mencapai 70 persen sampai 80 persen. Pada survei 2005, sebanyak 491 (74,4 persen) dari 639 responden menyatakan telah mendapat kekerasan dari polisi. Sebanyak 30 responden (4,5 persen) menyatakan pernah mendapat kekerasan sipir, 6 responden $(0,9$ persen $)$ mendapat kekerasan dari TNI, dan 4 responden $(0,6$ persen) mendapat kekerasan dari Penyidik Pegawai Negeri Sipil (PPNS). Pada survei 2008, disebutkan juga bahwa sebanyak 83,65 persen dari 367 responden atau 307 responden menyatakan saat berada di tingkat kepolisian, baik saat penangkapan maupun pemeriksaan, mengalami kekerasan ("Hari Antipenyiksaan: Menggugat Kekerasan Dalam Penegakan Hukum", diakses melalui: http://lama.elsam.or.id/ mobileweb/article.php?act=content $\& \mathrm{~m}=2 \&$ id $=652 \&$ cid $=101 \&$ lang $=$ in, diakses pada tanggal 15 Oktober 2016).

Secara khusus pada wilayah DKI Jakarta, dalam penelitian LBH Jakarta pada tahun 2005 ditemukan 81,1\% tersangka mengalami penyiksaan saat diperiksa di tingkat kepolisian. Angka bertambah pada tahun 2008, ditemukan bahwa 83,65\% mereka yang pernah diperiksa di kepolisian mengaku mengalami penyiksaan. Angka ini mengejutkan karena muncul di lima wilayah di DKI Jakarta yang selama ini dianggap sebagai parameter situasi hukum 
di Indonesia. Lebih mengejutkan lagi, 77\% penyiksaan dilakukan untuk memperoleh pengakuan dan mendapatkan informasi. Padahal pengakuan hanya salah satu dari lima alat bukti yang dapat digunakan oleh aparat kepolisian. Penyiksaan terjadi secara merata di lima wilayah di DKI Jakarta, dengan motivasi dan pola yang serupa yaitu penyiksaan secara fisik $57,8 \%$, secara psikis $71,4 \%$, dan secara seksual $30 \%$. Bahkan $67,6 \%$ mengalami penyiksaan bentuk ganda yang dapat mencapai 15 jenis tindakan penyiksaan yang dilakukan terhadap seseorang. Dari penelitian yang sama, tipologi korban penyiksaan adalah $73 \%$ dari keseluruhan anak, 84,4\% dari keseluruhan laki-laki, dan $76 \%$ dari keseluruhan perempuan. Selain itu, penelitian mengungkapkan bahwa tindakan penyiksaan kerap disertai dengan pelanggaran hak-hak tersangka lainnya. Selain di siksa tersangka dan terdakwa yang menjadi korban penyiksaan juga mengalami pelanggaran hak yang dilakukan aparat, termasuk ditangkap dan ditahan secara tidak sah, tidak didampingi kuasa hukum, dilarang untuk dikunjungi, tidak diberi makan dan minum, dan lainlain (Nurkholis Hidayat dan Restaria F. Hutabarat (Ed.), 2012: 4-5). Data-data empirik tersebut, terkonfirmasi melalui berbagai putusan pengadilan yang membatalkan surat dakwaan dan tuntutan dari Jaksa Penuntut Umum yang disebabkan proses penyidikan melanggar Pasal 53 KUHAP jo Pasal 117 ayat (1) KUHAP.

Putusan Mahkamah Agung RI Nomor 1531 K/Pid.Sus/2010 yang membatalkan putusan judex facti dengan pertimbangan hukum adanya rekayasa keterangan saksi dari Kepolisian dan perilaku pemerasan, dan memvonnis bebas kepada Terdakwa. Putusan tersebut mengandung makna, dimana secara a contratio, perolehan alat bukti yang melanggar Pasal 52 KUHAP menjadi tidak memiliki kekuatan hukum yang sah sebagaimana disyaratkan oleh Pasal 183 KUHAP. Sedangkan pada
Putusan Mahkamah Agung RI Nomor 1531 K/Pid.Sus/2010 tersebut, diketahui Tersangka/Terdakwa menjalani masa penahanan semenjak tanggal 21 Juni 2009 hingga 23 Juli 2010, dan baru mendapat kepastian dan keadilan pada tanggal $27 \mathrm{Juli}$ 2010. Artinya, tersangka/terdakwa baru memperoleh keadilan dengan dilepaskan dari masa penahanan setelah mendekam dalam tahanan selama lebih dari 1 (satu) tahun.

Pada kasus Narkotika yang terjadi di Surabaya, dimana tersangka/terdakwa mengalami upaya paksa penahanan semenjak 7 Agustus 2011, dan terakhir masih dalam kondisi ditahan dalam proses pemeriksaan tingkat banding pada $22 \mathrm{Mei}$ 2012. Namun, judex juris membebaskan Tersangka/Terdakwa, dikarenakan adanya rekayasa alat bukti oleh Penyidik ("Rekayasa Kasus Narkoba, Polisi Tak Mengetes Urine Rudy", Sumber: http:// kambrium.blogspot.co.id/2015/02/rekayasa -kasus-narkoba-polisi-tak.html, diakses pada tanggal 16 April 2016). Sedangkan dalam kasus rekayasa alat bukti pada Polres Jakarta Pusat, menyidangkan secara etik terhadap Penyidiknya, namun perkara terus berjalan dan tetap diperiksa oleh Pengadilan Negeri Jakarta Pusat ("Diduga Merekayasa Keterangan Saksi, Dua Polisi Diperiksa", Sumber: https://m.tempo.co/ $\mathrm{read} /$ news/2010/02/19/064227075/didugamerekayasa-keterangan-saksi-dua-polisidiperiksa, diakses pada tanggal 16 April 2016).

Berdasarkan uraian-uraian tersebut, menjadi menarik untuk dibahas dan dituangkan dalam penulisan ilmiah ini guna mencari relevansi antara Ilmu Hukum dan Psikologi Hukum pada konteks keterkaitannya dengan proses penegakan hukum pidana di Indonesia.

\section{Pembahasan}

Perkembangan ilmu pengetahuan, hubungan antara satu ilmu bisa saling berkaitan satu sama lain. Bahkan pada setiap hubunganya tidak hanya sebatas 
sebagai pelengkap tetapi juga bisa menjadi suatu yang bersifat inheren. Hal ini disebabkan perkembangan ilmu pengetahuan, informasi dan teknologi menimbulkan permasalahan yang begitu kompleks pada kehidupan manusia. Dalam memahami sesuatu, tidak hanya cukup dengan menggunakan satu pendekatan saja, melainkan dibutuhkan suatu pendekatan yang bersifat holistik, artinya dalam memahami realitas khususnya berkaitan dengan perilaku manusia perlu suatu pendekatan interdisipliner ilmu. Pendekatan ini sangat relevan bila mengkaji suatu masalaah yang begitu kompleks seperti permasalahan hukum (Ivan Muhammad Agung. Kontribusi Psikologi dalam Penegakan Hukum di Indonesia, Sumber : https://vano2000.files.wordpress.com/2012/ 06/kontribuasi-psikologi-dalam-penegakanhukum-di-indonesia.pdf, diakses pada tanggal 15 Oktober 2016).

Keterkaitan antara ilmu-ilmu yang berobjek hukum dengan Ilmu Hukum, dimulai dari semenjak munculnya Aliran Neo-Klasik dalam Filsafat Pemidanaan. Kajian Psikologi Hukum, menjadi suatu referensi bagi penegak hukum, khususnya Hakim, guna membentuk pertimbangan hukum dan putusan hukum dalam konteks menjatuhkan vonnis kepada terdakwa. Permasalahannya adalah relevansi Psikologi Hukum dalam Aliran Neo-Klasik yang penggunaannya baru sebatas mengkaji perilaku dari tersangka/terdakwa dalam melakukan perbuatan pidana. dimana, Aparat Penegak Hukum menjadi terlewatkan sebagai subjek hukum yang dibebankan melakukan pemeriksaan terhadap tersangka/terdakwa. Sehingga, seringkali tersangka/terdakwa menjadi korban dari penyalahgunaan kewenangan (detournement de pouvoir atau onrechtmatige overheidsdaad) dari Penyidik Polri.

Kajian Psikologi Hukum meru-pakan bidang yang baru lahir di sekitar tahun 1960-an sebagai salah satu kajian empiris, yang memandang hukum dalam wujudnya sebagai "behavior" atau "peri-laku" manusia dalam bidang hukum. Ketika manusia berperilaku, apakah perilakunya itu "benar" atau "salah" menurut standar hukum, maka di lain pihak, psikologi hukum ingin mengklarifikasi perilaku manusia itu dalam klasifikasinya sendiri. Seperti klasifikasi antara perilaku individu dan perilaku kelompok, antara perilaku normal dan perilaku abnormal, dan sejumlah klasifikasi khas psikologi hukum lainnya (Achmad Ali, 2009: 2).

Psikologi hukum mencakup kajiankajian empiris, yakni: penelitian psikologi terhadap hukum, tentang institusi hukum, dan tentang orang yang berhubungan dengan hukum. Psikologi hukum secara tipikal sebagai kajian yang merujuk pada dasar sosial dan teori-teori serta asas-asas yang bersifat kognitif, untuk menerapkan mereka terhadap isu-isu dalam sistem hukum seperti memori saksi mata, pengambilan keputusan dewan juri, penyelidikan, dan pewawancaraan. Istilah "legal psychology" dibedakan dengan istilah "forensic psychology" dimana gabungan antara keduanya itulah yang dkenal sebagai "psychology and law" (Achmad Ali, 2009: 4).

Munculnya ide terhadap pentingnya peran psikologi dalam hukum di negara yang ilmu pengetahuannya maju, Inggris dan Amerika Serikat misalnya, ternyata juga tidak lantas disambut oleh kalangan psikologi. Masyarakat Psikologi-Hukum Amerika baru berdiri tahun 1968. Divisi Kriminologi dan Psikologi Hukum Masyarakat Psikologi Inggris berdiri tahun 1977. Sedangkan Divisi PsikoIogi dan Hukum dari APA (American Psychology Association) yang merupakan divisi ke-41 baru muncul pada tahun 1981. Dengan demikian, antisipasi masyarakat psikologi terhadap kebutuhan hukum akan psikologi tidak secepat yang dibayangkan. Dimana saja sebenarnya psikologi bisa memberi sumbangan pada hukum ? Dalam tulisannya yang termuat di British Journal of Psychology Volume 79 edisi 1988, 
Lloyd-Bostock mengemukakan ada beberapa bidang hukum yang telah dikaji dan diintervensi psikologi. Reliabilitas saksi, proses pengambilan keputusan pengadilan, pemidanaan anak-anak, dinamika kelompok juri (di Indonesia tidak melibatkan juri dalam proses peradilan), adalah contoh dari bidang yang sangat relevan bila dicampur-tangani psikologi (Faturrochman, 1989).

Pengertian secara sempit diutarakan oleh Soerjono Soekanto (1980: 17-18) yang menjelaskan bahwa Psikologi hukum di satu pihak, yaitu menelaah faktor-faktor psikologis yang mendorong orang untuk mematuhi hukum, dilain pihak juga meneliti faktor-faktor yang mungkin mendorong orang untuk melanggar hukum. Dalam pengertian tersebut, Soerjono Soekanto masih membahas kegunaan psikologi hukum yang ketertujuannya adalah individu yang melakukan perbuatan pidana dan ketaatan terhadap hukum. Sedangkan, melalui data empirik dan data primer tersebut di atas, nampak jelas Penyidik Polri pun dapat melakukan perbuatan yang melanggar hukum demi kepentingan jabatannya yaitu Penyidik.

Ketidaksepakatan Penulis dengan ungkapan tersebut, berangkat dari asumsi bahwa hukum bukan hanya untuk masyarakat, namun hukum juga mengikat kepada seluruh badan-badan (institusi) negara. Walaupun jika mengacu kepada pendapat Cicero yang mengatakan bahwa hukum muncul dari masyarakat, namun yang perlu dipahami adalah aparat penegak hukum juga merupakan bagian dari masyarakat itu sendiri. Sehingga, Ilmu Hukum sebagai ilmu yang ilmu yang kritis, dimana ketertujuannya bukan hanya ditujukan kepada individu sebagai bagian dari masyarakat, namun pula ditujukan kepada institusi penegak hukum sebagai bagian dari masyarakat pula.

Lepasnya pengamatan Ilmu Hukum terhadap institusi penegak hukum, berangkat dari perbedaan kemunculan lembaga Polri. Dalam ranah sistem hukum common law, Polisi dibentuk berdasarkan embrio yang dibangun oleh masyarakat itu sendiri, sekitar tahun 1850-an, guna menjaga kepentingan keamanan masyarakat tertentu yang membentuknya. Sehingga, paradigma kepolisian pada masa itu adalah melayani masyarakat yang membentuknya. Baru pada tahun 1860, muncul wacana Kepolisian merupakan instrumen penting dalam sistem peradilan pidana pada pemerintahan kota tertentu. Hal tersebut berbeda dengan kemunculan Polri di Indonesia, walaupun diawali dengan peristiwa hukum yang sama, yaitu Polisi awalnya dibentuk pula oleh masyarakat. Namun, masyarakat yang dimaksud adalah kalangan borjuis dari masyarakat Eropa guna melindungi asset kekayaannya dari orang pribumi dengan sistem rekrutmen. Sehingga, polisi pada tahun 1867 tersebut ("Sejarah Polri", Sumber: https://www.polri.go.id/pdf/Sejarah\%20Polri.pdf, diakses pada tanggal 15 Oktober 2016), memiliki cara pandang sebagai perpanjangan tangan masyarakat Eropa sebagai penjajah. Kemudian Polri secara modern yang dibentuk oleh Pemerintah Hindia Belanda pada tahun 1897-1920 ("Sejarah Polri", Sumber: https://www.polri.go.id/pdf/Sejarah\%20Polri.pdf, diakses pada tanggal 15 Oktober 2016).

Kemudian mulai tanggal 1 Juli 1946 dengan Penetapan Pemerintah tahun 1946 No. 11/S.D. Djawatan Kepolisian Negara yang bertanggung jawab langsung kepada Perdana Menteri. Tanggal 1 Juli 1946 inilah yang setiap tahun diperingati sebagai Hari Bhayangkara hingga saat ini. Polri menyatakan dirinya "combatant" yang tidak tunduk pada Konvensi Jenewa. Perkembangan lebih lanjut, pertumbuhan Polri sangat dipengaruhi oleh suasana perpolitikan dan kekuasaan. Hingga pada akhirnya, melalui Ketetapan MPRS No. II Tahun 1960 jo Ketetapan MPRS No. III Tahun 1960 jo Undang-Undang Nomor 13 Tahun 1961 tentang Ketentuan-Ketentuan Pokok Kepolisian Negara (UU No. 13/1961) jo Undang-Undang Nomor 28 
Tahun 1997 tentang Kepolisian Negara Republik Indonesia (UU No. 28/1997) jo Surat Keputusan Presiden Nomor 132 Tahun 1967 tertanggal 24 Agustus 1967 yang meletakkan Polri ke dalam susunan ABRI sederajat dengan Angkatan Darat, Angkatan Laut dan Aangkatan Udara.

Baru setelah reformasi tahun 1999, melalui keputusan politis terjadi pemisahan antara TNI dan Polri, yang kemudian ditetapkan dalam Ketetapan MPR No. VI Tahun 2000 jo Ketetapan MPR No. VII Tahun 2000, yang kemudian diperkuat dengan diundangkan dan disahkan UU No. 2/2002. Namun, dalam sistem ketatanegaraan Indonesia melalui Pasal 30 ayat (4) UUD NRI 1945, Polri kemudian diklasifikasikan sebagai "alat negara".

Berdasarkan uraian sejarah tersebut, terlihat budaya organisasi Polri sebagai "combatant" berlangsung selama puluhan tahun. Baru pada tahun 2002, terjadi pergeseran paradigma dimana Polri sebagai pelayan dan pengayom masyarakat. Dikaji dari sisi paradigma, semenjak kemunculan bentuk Polri pertama, memposisikan Polri sebagai perpanjangan tangan penguasa terhadap masyarakat. Bahkan, dalam pasca amanademen UUD 1945 menjadi UUD RI 1945 pun, masih meletakkan Polri sebagai "alat negara". Sehingga, budaya organisasi yang terbangun tidaklah jauh berbeda dengan cara pandang Polri sebelumnya terhadap masyarakat.

Terhadap hal tersebut, Suwarni (Suwarni, 2009: 16-18) berpendapat bahwa kegagalan reformasi mengakibatkan budaya organisasi Polri menjadi kajian utama yang perlu mendapat perbaikan. Demikian pula pendapat dari Farouk Muhammad yang menegaskan kegagalan reformasi Kepolisian karena akibat pengabaian aspek kultural, khususnya nilai-nilai, sikap dan norma-norma kerja. Selain aspek kultur budaya organisasi tersebut, menarik untuk dikaji aspek psikologis dari sistem keberseragaman dari atribut Polri yang seringkali diingkari untuk dikaji sebagai salah satu unsur dari perwujudan sikap dan perilaku Penyidik Polri sebagai sosok yang arogan, yaitu aspek psikologis.

Dalam menjalankan tugasnya ter-dapat beberapa aspek-aspek yang dapat turut membentuk kapasitasnya, terutama terkait dengan proses menjalankan peker-jaannya. Salah satu diantaranya adalah faktor psikologis yang menjadi bagian dalam menjalankan tugasnya yang di-pengaruhi oleh adanya "seragam", "pangkat" dan "senjata api". "Seragam" merupakan hal yang menjadi pembeda antara polisi dan militer, antara masyarakat umum dengan orang-orang yang menjadi anggota kepolisian. Hasil penelitian yang diungkap oleh De Camargo (2012), penggunaan seragam dan profesi kepolisian biasanya dapat memberikan kontaminasi terhadap kehidupan. Yaitu kontaminasi mendapatkan kepemilikan keadaan per-sonal, berupa kepemilikan titel status tertentu. Seperti yang diuraikan oleh Herzog (2001), bahwa tampilan polisi menjelaskan kepemilikan tentang profesional police goals. Yaitu berperang melawan kejahatan dan juga memberikan pelayanan. Karenanya banyak peristiwa yang ditemukan di masyarakat yang memperlihatkan adanya penambahan terhadap keadaan psikologis tertentu pada orang-orang yang mengenakan seragam polisi. Baik itu polisi yang sebenarnya, maupun masyarakat sipil yang mengenakan seragam polisi untuk kepentingan tertentu. Adapun berkaitan dengan jenjang "pangkat" menggambarkan tentang tingkat dan keudukan seluruh anggota di dalam struktur kepolisian. Jenjang pangkat terkadang dikaitkan dengan keadaan-keadaan psikologis dalam melakukan pengelolaan pekerjaan. Dari hasil studi penyelidikan yang dilakukan Sidanius, Liu, Shaw dan Pratto (1994) dapat diketahui bahwa kepangkatan pada bidang kepolisian sering dikatikan dengan pandanganpandangan yang berhubungan dengan dominasi sosial. Demikian pula dengan adanya atribut "senjata api". "Senjata api" (firehand/handgun) adalah salah satu alat penunjang yang dipakai untuk melakukan 
tugas-tugas bidang dalam menjaga keamanan. Dalam proses penggunaannya pun diperlukan serangkaian pemeriksaan psikologis. Hal ini sering dikaitkan dengan kondisi-kondisi psikologis yang dapat memengaruhi perilaku penggunaannya. Diuguid (2014) menjelaskan bahwa kepemilikan senjata api (guns) memberikan orang-orang yang memegangnya perasaan (sense) tentang kekuatan dan kontrol keamanan, tetapi pada sisi yang lainnya juga membentuk adanya rasa takut dan kekhawatiran tentang dampaknya yang bisa melukai orang lain. Dalam sebuah gambaran laporan teknis (technical report 1996) tentang psychological evaluation and gun control. Tertulis bahwa senjata api memiliki dampak psikologis tertentu, karena sering dikaitkan dengan penggunaannya yang bisa melukai atau menghilangkan nyawa orang lain, dan juga melukai atau menghilangkan nyawa sendiri (Erik Saut H. Hutahaean, 2015: 29-30).

Aspek budaya hukum dan aspek psikologis merupakan bagian dari Ilmu Sosial yang diklasifikasikan sebagai IlmuIlmu Manusia (geisteswissenchaften), termasuk di dalamnya Ilmu Hukum. Namun, antara Ilmu Hukum dengan Ilmu Sosial memiliki proses kerja yang berbeda. Walaupun dalam tataran sistematika eksternal, pada kegiatan ilmiah Ilmu Hukum, pun tidak menafiqkan kontribusi dari Ilmu Sosial. Sebagaimana diinginkan oleh Oliver Wendell Holmes, Jr yang menegaskan untuk menguasai setiap bidang pengetahuan, maka Anda harus menguasai bidang-bidang lain yang ada di sampingnya. Yang kemudian Achmad Ali (2012: 94) menjelaskan, hukum tidak dapat ditemukan hanya dengan melakukan penyelidikan terhadap aturan-aturan hukum. Pemusatan perhatian hanya pada aturan-aturan tersebut justru akan membahayakan profesi hukum, karena pemusatan seperti itu akan mengarahkan kepada pengabaian terhadap konteks yang lebih luas yang telah memberikan makna sosial bagi hukum.
Konvergensi dalam Ilmu Hukum tersebut membutuhkan konsistensi dalam proses berfikir berdasarkan konsep-konsep, pengertian-pengertian dan sarana-sarana yang diakui dan diharapkan oleh Ilmu Hukum guna diterapkan dalam konteks penawaran alternatif solusi terhadap permasalaha nyata. Oleh karena itu, Ilmu Hukum telah mendeskripsikan kepada kita berkaitan mengenai kegiatan ilmiah yang harus dilalui oleh setiap Ilmuwan Hukum dalam proses pengambilan keputusa tersebut. Dalam hal ini, menurut Penulis, sebagai akibat metode penelitian dan metode pengambilan keputusan yang tidak tepat, sehingga adalah suatu kewajaran jika pada kasus-kasus yang diangkat dalam penulisan ini, menunjukan adanya kondisi sesat pikir (E. Sumaryono, 1999: 9) oleh Penyidik dan Penyelidik Polri.

Penyelesaian permasalahan ter-hadap suatu persoalan kemasyarakatan selain menggunakan refleksi kefilsafatan terhadap aspek ontologis, epistemologis dan aksiologis, maka proses tersebut hendaknya melalui kegiatan Ilmu Hukum yaitu dengan menghimpun, memaparkan, mensistematisasi, menganalisis, menginterpretasi dan menilai hukum positif dimana pada analisis terakhir diarahkan guna memunculkan serta memberikan solusi penyelesaian terhadap masalah hukum bertumpu dan dalam kerangka tatanan hukum yang berlaku.

Pada akhirnya, putusan yang dihasilkan harus dapat ditempatkan dalam tatanan hukum yang berlaku dan ke dalam tatanan kemasyarakatan yang di dalamnya tatanan hukum itu merupakan salah satu subsistemnya, disebut sebagai sistematisasi-eksternal material hukum yang menjadi entry point bagi pendekatan deskriptif-nomologis dan masukan dari Ilmu-Ilmu Manusia lainnya khususnya Ekonomi, Sosiologi, Antropologi, Psikologi, Politik dan Sejarah yang merupakan "ingredients" yang harus diolah menjadi "adonan" bagi pengembanan Ilmu Hukum 
untuk memproduksi proposisi yuridis dan teori hukum.

Menurut Bernard Arief Sidharta (2013: 76), dengan melaksanakan fungsi sistematisasi-eksternal, maka pengembanan Ilmu Hukum sudah dijalankan dengan mengacu kepada Strategi Ilmu Sosial yang memungkinkan Ilmu Hukum itu menjadi hidup dan relevan terhadap dinamika kehidupan bermasyarakat dan bernegara, namun pengolahan akhir berbagai masukan ini tetap hanya dapat dilakukan dengan menggunakan metode normatif yang mengacu pada nilai dan kaidah. Bagaimanapun, Ilmu Hukum dalam pengembanannya selalu harus mengacu dan berintikan rasionalitas-nilai dan rasionalitas-berkaidah tanpa mengabaikan rasionalitas-efesiensi dan rasionalitaskewajaran. Dapat dikatakan sesungguhnya dalam pengembanan Ilmu Hukum itu sekaligus mengakomodasikan ke dalam diri Psikologi Hukum, Sejarah Hukum, Sosiologi Hukum, Antropologi Hukum dan Teori Keadilan. Dengan demikian, pengkajian terhadap permasalahan hukum (mikro dan makro), dengan pendekatan Ilmu-Ilmu Sosial sebagai pelengkap dari kegiatan ilmiah Ilmu Hukum, hendaknya tidak mengubah kegiatan tersebuat menjadi kegiatan ilmiah Ilmu Sosial, dengan tetap berpendirian Ilmu Hukum sebagai ilmu normatif.

Berkaitan dengan digunakannya Psikologi Hukum, dalam menjalankan fungsi dan tugas pokok Polri, khususnya bagi Penyidik Polri, dalam konteks penegakan hukum pada Sistem Peradilan Pidana, seringkali diabaikan. Polri dalam membina anggota-anggotanya lebih terjebak kepada perbaikan budaya organisasi daripada aspek psikologis Anggota Polri dalam melakukan penegakan hukum. Penyimpangan-penyimpangan dari perilaku Penyidik Polri dalam melaksanakan tugasnya, oleh karena, pengabaian Psikologi Hukum sebagai "ingredient" dalam pengambilan keputusan hukum sebagai bagian dari Startegi Ilmu Sosial ditam- pilkan dengan sangat elok oleh Erik Saut $\mathrm{H}$. Hutahaean (2015: 34-35) dalam penelitiannya mengenai atribut Polri. Beliau memberikan kesimpulan sebagai berikut:

"Seragam, pangkat dan senjata api memberikan pengaruh yang dapat membentuk keadaan psikologis tertentu saat memiliki dan mengenakannya. Seragam, pangkat dan senjata api merupakan tiga hal yang melekat pada tugas-tugas kepolisian. Masing-masing dapat berperan dalam membentuk keadaan psikologis tertentu pada orang-orang yang menggunakannya, dan bahkan juga terhadap orang-orang yang melihat dan menyadari keberadaan anggota polisi yang menggunakan seragam. Pangkat merupakan gambaran yang terkait pembentukan keadaan psikologis dalam menjalankan fungsi dan peran kerja dalam sebuah organisasi tugas. Yaitu sebagai pelaksana perintah untuk jenjang pangkat yang lebih rendah, sebagai penghubung yang dapat menjamin lancarnya pekasanaan perintah, dan juga sebagai pemimpin di dalam organisasi kerja (untuk perwira). Keterbatasan akan data yang digambarkan dalam penelitian ini, merupakan data yang mendasar saja, data yang didapatkan berdasarkan wawancara untuk dapatkan gambaran saja. Karenanya data yang didapatkan hanya sedikit dan bersifat umum, sehingga melibatkan hasil kajian dari literatur sebelumnya untuk memberikan penjelasannya. Untuk lebih memperdalam analisa mengenai atribut seragam, pangkat dan senjata api yang terkait dengan psikologi kepolisian. Perlu dilakukan studi lebih lanjut lagi kepada bentukbentuk penyimpangan (deviansi) dalam melakukan tugas dinas dan mengenai wewenangnya. Sehingga dapat dikenali dengan lebih jelas 
mengenai faktor pembentuk terjadinya penyimpangan."

Terhadap penggunaan Psikologi Hukum tersebut, Penulis kemudian mengacu kepada pandangan Ronny Nitibaskara dan Bambang Umar Widodo, yang menjelaskan bahwa perkembangan hukum tidak terlepas dari aspek normatif dan aspek sosiologis. Dalam kenyataannya, aspek normatif dan aspek sosiologis tersebut saling terkait, saling melengkapi, dan saling kontradiksi dalam implimentasinya. Berkaitan dengan perilaku Penyidik Polri dalam melakukan kekerasan terhadap tersangka, oleh Ronny Nitibaskara, diklasifikasikan sebagai judicial crime dalam konteks law as a tool of crime, yaitu perbuatan jahat dengan menggunakan hukum sebagai alatnya menjadi sulit untuk dilacak karena diselubungi oleh Hukum dan berada dalam Hukum. Dimana kejahatan yang dilakukan oleh aparat penegak hukum, yaitu dengan menyalahgunakan jabatan yang membuat orang bersalah atau tidak bersalah. Kewenangan yang dimiliki seorang penegak hukum, akan menimbulkan multitafsir tatkala 'kebebasan' tersebut dianggap oknum yang bersangkutan sebagai keleluasaan untuk melakukan perbuatan menguntungkan diri sendiri dengan memanfaatkan hukum sebagai alatnya (law as tool of crime) (Jufrina Rizal dan Suharyono AR (Ed), 2016: 570).

Pada tataran aplikatif, peranan Psikologi Hukum masih diterapkan secara terbatas. Peranan seorang Psikolog saat ini hanya terbatas pada pemeriksaan sisi kejiwaan dari tersangka/terdakwa baik dalam pemeriksaan penyidikan maupun dalam persidangan. Dengan demikian, peranan Psikologi Hukum, pula terbatas dalam bidang Psikologi Forensik. Sedangkan pada arah sebaliknya, terhadap penegak hukum, Psikologi Hukum hanya digunakan dalam proses penerimaan pegawai/karyawan dari institusi penegak hukum, namun Psikologi Hukum belum pernah digunakan terhadap Penyidik Polri yang melakukan kekerasan, baik psikis maupun fisik, terhadap tersangka dalam proses pemeriksaan Penyidikan. Psikologi Hukum, dalam hal ini adalah Psikologi Forensik, terhadap penegak hukum baru akan digunakan pada saat seorang Anggota Kepolisian menyalahgunakan kewenangannya dalam penggunaan senjata api, dikaitkan dengan apakah layak atau tidak layak si Anggota Polri untuk menggunakan senjata api di kemudian hari.

\section{Simpulan}

Berdasarkan uraian-uraian tersebut di atas, maka dari sisi kajian Psikologi Hukum dalam konteks Ilmu Hukum Normatif sebagai bagian dari Strategi Ilmu Sosial, penggunaan atribut baik berupa seragam, pangkat dan senjata api me-munculkan perubahan sikap mental dan perilaku dari seseorang Penyidik Polri. Namun, dalam konteks Ilmu Hukum, kajian Psikologi Hukum tersebut tidaklah mungkin dilepaskan dari aspek kajian Budaya Hukum yang melahirkan budaya organisasi.

Pada pengembanan hukum (rechtsbeoefening) baik yang bersifat praktis maupun teoretis, seorang Ilmuwan Hukum (akademisi dan praktisi hukum) seringkali mengabaikan kajian-kajian dari aspek sosial. Dalam hal ini, seorang Ilmuwan Hukum (akademisi dan praktisi hukum) terjebak dan terkungkung pada sifat Ilmu Hukum sebagai ilmu normatif. Sehingga, pengembanannya seringkali berbenturan dalam tataran praktik hukum dalam kaitannya pemenuhan rasa keadilan masyarakat. bahkan, terhadap Aparat Penegak Hukum khususnya Penyidik Polri, berdasarkan pola pendidikannya, jelas sekali lebih mengutamakan perbaikan budaya hukum dan mengesampingkan Psikologi Hukum.

Sehingga, hampir bisa dipastikan, seorang Penyidik Polri dalam melaksanakan tugas dan fungsinya tidak akan pernah lepas, bahkan, masih terjebak 
dengan asas inquisatoir dalam melakukan pemeriksaan penyidikan.

\section{Daftar Pustaka}

Achmad Ali. ( 2012). Menguak Teori Hukum (Legal Theory) dan Teori Peradilan (Judicialprudence) Termasuk Interpretasi UndangUndang (Legisprudence). Volume I, Jakarta: Kencana.

Achmad Ali. (2009). Psikologi Hukum, Makasar: FH-UNHAS.

Bernard Arief Sidharta. (2013). Ilmu Hukum Indonesia. Upaya Pengembangan Ilmu Hukum Sistematik Yang Responsif Terhadap Perubahan Masyarakat, Yogyakarta: Genta Publishing.

Bernard Arief Sidharta. (2009). Refleksi Tentang Struktur Ilmu Hukum, Bandung: Mandar Maju.

E. Sumaryono. (1999). Dasar-Dasar Logika, Yogyakarta: Kanisius.

Johnny Ibrahim.(2006) Teori dan Metodologi Penelitian Hukum Normatif, Malang: Bayumedia Publishing.

Jufrina Rizal dan Suharyono AR (Ed). (2016) Demi Keadilan: Antologi Hukum Pidana dan Sistem Peradilan Pidana. 6 Dasarwarsa Harkristuti Harkrisnowo, Jakarta: Pustaka Kemang.

Nurkholis Hidayat dan Restaria F. Hutabarat (Ed.). (2012). Mengukur Realitas dan Persepsi Penyiksaan di Indonesia, Jakarta: The Partnership for Governnance Reform.

Otje Salman. (2004, 2005). Metode Penelitian Hukum, Bahan Ajar Fakultas Hukum Universitas Padjadjaran.

Soerjono Soekanto dan Sri Mamudji.(1983). Penelitian Hukum Normatif, Suatu Tinjauan Singkat, Jakarta : Radja Grafindo Persada.

Soerjono Soekanto. (1980) Pokok-Pokok Sosiologi Hukum, Jakarta: Rajawali Press.
Suwarni. (2009) Perilaku Polisi. Studi atas Budaya Organisasi dan Pola Komunikasi, Bandung: Nusamedia.

"Diduga Merekayasa Keterangan Saksi, Dua Polisi Diperiksa", Sumber: https://m.tempo.co/read/news/2010/02/ 19/064227075/diduga-merekayasaketerangan-saksi-dua-polisi-diperiksa, diakses pada tanggal 16 April 2016.

"Hari Anti penyiksaan: Menggugat Kekerasan Dalam Penegakan Hukum", diakses melalui: http://lama.elsam.or.id/mobileweb/artic le.php?act $=$ content $\& \mathrm{~m}=2 \& \mathrm{id}=652 \& \mathrm{cid}$ $=101 \&$ lang $=$ in, diakses pada tanggal 15 Oktober 2016.

"Rekayasa Kasus Narkoba, Polisi Tak Mengetes Urine Rudy", Sumber: http://kambrium.blogspot.co.id/2015/0 2/rekayasa-kasus-narkoba-polisitak.html, diakses pada tanggal 16 April 2016.

"Sejarah Polri", Sumber: https://www.polri.go.id/pdf/Sejarah\%2 OPolri.pdf, diakses pada tanggal 15 Oktober 2016.

Erik Saut H. Hutahaean. (2015). Psikologi Kepolisian: Seragam, Pangkat dan Senjata Api, Prosiding PESAT, Volume 6.

Faturrochman. (1989). Sumbangan Psikologi pada Hukum, Suara Merdeka, tanggal 1 Desember 1989.

Ivan Muhammad Agung. Kontribusi Psikologi dalam Penegakan Hukum di Indonesia, Sumber https://vano2000.files.wordpress.com/2 012/06/kontribuasi-psikologi-dalampenegakan-hukum-di-indonesia.pdf, diakses pada tanggal 15 Oktober 2016.

Peter Mahmud Marzuki, Karakteristik Ilmu Hukum, Sumber (online): http://download.portalgaruda.org/articl e.php? article $=18635 \&$ val $=1156$, diakses pada tanggal 20 Agustus 2016.

Undang-Undang Dasar Negara Republik Indonesia Tahun 1945

Ketetapan MPRS No. II Tahun 1960

Ketetapan MPRS No. III Tahun 1960 
Ketetapan MPR No. VI Tahun 2000

Ketetapan MPR No. VII Tahun 2000

Undang-Undang Nomor 13 Tahun 1961 tentang Ketentuan-Ketentuan Pokok Kepolisian Negara (UU No. 13/1961)

Undang-Undang Nomor 28 Tahun 1997 tentang Kepolisian Negara Republik Indonesia (UU No. 28/1997)

Undang-Undang Nomor 2 Tahun 2002 tentang Kepolisian Negara Republik Indonesia (UU No. 20/2002)

Surat Keputusan Presiden Nomor 132

Tahun 1967 tertanggal 24 Agustus 1967 
Psympathic, Jurnal Ilmiah Psikologi Desember 2016, Vol. 3, No. 2, Hal: 201 - 212 